\title{
A comparative genetic diversity assessment of industrial and household Brazilian cassava varieties using SSR markers
}

\author{
Marcos Vinicius Bohrer Monteiro Siqueira ('); Aline Borges ('); Teresa Losada Valle ( ${ }^{2}$ ); \\ Elizabeth Ann Veasey $\left({ }^{*}\right)$ \\ (') Universidade de São Paulo (USP), Escola Superior de Agricultura “Luiz de Queiroz” (Esalq), Departamento de Genética, \\ Caixa Postal 83, 13418-900 Piracicaba (SP), Brasil. \\ (2) Instituto Agronômico, Caixa Postal 28, 13012-970 Campinas (SP), Brasil. \\ (*) Corresponding author: eaveasey@esalq.usp.br
}

Received: April 12, 2011; Accepted: August 11, 2011

\begin{abstract}
This study was carried out in order to assess the genetic diversity of 20 cassava (Manihot esculenta Crantz) genotypes with high phenotypic performance using microsatellite markers. Two groups were considered for this study: eleven varieties for industrial uses and nine for household consumption. By using nine microsatellite primers, high polymorphism was identified in all the loci analyzed, with values reaching 100\%. On average, 3.4 alleles per locus were found, with 0.371 the value estimated for the observed heterozygosity and 0.555 for gene diversity for the entire set of varieties. The genetic variability found in both varieties, cultivated on a large-scale in the South Center region of Brazil, is wide enough to allow the choice of divergent parental genotypes to be used in crosses to obtain new recombinant genotypes. Furthermore, the analyses indicated a high genetic variability within the two groups (I: varieties for industrial uses; II: varieties for household consumption). However, varieties for household consumption attain higher genetic variability, probably due to high priority placed on selection of different sensorial traits. In the cluster analysis, a tendency for separation of varieties for industrial use and household consumption was verified. Our results represent an important source of information to the cassava breeding program in Brazil.
\end{abstract}

Key words: Manihot esculenta, genetic diversity, germplasm, microsatellites.

\section{Avaliação comparativa da diversidade genética de variedades brasileiras de mandioca industriais e de mesa usando marcadores SSR}

\begin{abstract}
Resumo
Este estudo teve como objetivo avaliar a diversidade genética de 20 genótipos de mandioca (Manihot esculenta Crantz) com alto desempenho fenotípico, utilizando marcadores microssatélites. Foram considerados dois grupos: onze variedades para fins industriais e nove variedades de mesa. A partir de nove iniciadores foi identificado alto polimorfismo para todos os locos analisados, atingindo valores de 100\%. Em média, foram encontrados 3,4 alelos por loco, sendo 0,371 o valor estimado para a heterozigosidade observada e 0,555 para a diversidade gênica, no conjunto total de variedades comerciais avaliadas. A variabilidade genética observada em ambos os grupos de variedades, cultivadas em larga escala na Região Centro-Sul do Brasil, é ampla o suficiente para permitir a escolha de genótipos parentais divergentes para serem utilizados em cruzamentos para obter novos genótipos recombinantes. Além disso, as análises revelaram alta variabilidade genética dentro dos dois grupos (I: variedades industriais; II variedades de mesa). Contudo, nas variedades de mesa houve maior diversidade genética, provavelmente devido à alta prioridade dada às características sensoriais. Pela análise de agrupamento, verificamos uma tendência para a separação das variedades industriais das de mesa. Os resultados representam importante fonte de informação para programas de melhoramento de mandioca no Brasil.
\end{abstract}

Palavras-chave: Manihot esculenta, diversidade genética, germoplasma, microssatélites.

\section{INTRODUCTION}

Cassava is one of the most important crops in tropical and subtropical regions. In 2009, the cultivated area for this crop included more than 18.9 million hectares worldwide, producing over 233 million tons of root tubers with 25.8 million tons produced in Brazil (FAO,
2011), where the annual average consumption reached $50.6 \mathrm{~kg} /$ person (IвGE, 2007).

Cassava consumption is widespread in Brazil, especially in rural areas where it is consumed by indigenous and traditional populations (Amorozo, 2000, 2008). In the South Center region, near the Tropic of Capricorn, in the States of Santa Catarina, São Paulo, 
Paraná and Mato Grosso do Sul, cassava is cultivated in different ways. In these regions, cassava fields are cropped by traditional farmers who use cassava for self- consumption, similarly to the way natives did, and, also, a considerable volume of cassava has been produced for commercial purposes.

Farmers who grow cassava for commercial purposes are classified in two groups: those who grow varieties for household consumption or sweet cassava, which are commercialized either in natura, or frozen at horticulture markets; and those that grow cassava industrially to produce starch and flour. Both groups grow a few cultivars of cassava, well-adapted to edaphoclimatic conditions and regional production systems, which show potential for high yield and resistance to biotic and abiotic stresses. Varieties for household consumption must present typical sensorial characteristics and low cyanogenic potential, whereas industrial varieties must show high dry weight potential and some level of cyanogenic acid (VAlLe et al., 2004). These varieties are developed by plant breeding programs or selected by the local farmers themselves.

In Brazil, cassava was first bred at the Agronomic Institute (IAC) in Campinas (SP), in the 1940s, playing an important role to produce genotypes that would greatly impact the agribusiness in Brazil and other countries. At first, the program aimed to assess the genetic diversity of the main genotypes which conveyed potential to be used as parents in directed crosses. Considering that most of these genotypes have been widely cultivated, a second purpose was to evaluate the genetic vulnerability of these cultivars (Villela et al., 1985; VAlle et al., 2004).

Molecular markers have been used in cassava to, among others objectives, analyze genetic diversity and/or varietal identification. RFLP (restriction fragment length polymorphism) (BeEching et al., 1993), AFLP (amplified fragment length polymorphism) (RAJI et al., 2009), RAPD (random amplified polymorphic DNA) (AsANTe and Offei, 2003; Zacarias et al., 2004; Ferreira et al., 2008), microsatellites (Chavarriaga-Aguirre et al., 1998; Fregene et al., 2003; Peroni et al., 2007; Raji et al., 2009; Siqueira et al., 2009, 2010) and occasionally the combination of various markers (MüHLEN et al., 2000; Carvalho and Schaal, 2001) have been used to carry out these genetic studies over the last decade. Microsatellites or SRR (simple sequence repeats), which are highly polymorphic and codominant markers, have been used in the identification of contrasting genotypes in plant breeding programs. These markers aid the search for potential genotypes, providing useful information of existing variability and association with phenotypic characteristics (RoA et al., 2000; KawUKI et al., 2011).

This study aimed to assess the genetic diversity of 20 high agronomic performance cassava genotypes cultivated in the Central Southern region in Brazil using SSR markers, in order to evaluate the level of genetic vulnerability of cassava in this region, and also to compare the genetic diversity among and within two cassava groups according to their use (varieties for industrial use and household consumption). Considering that there is a relatively small number of local varieties and that others originated from plant breeding programs are cultivated in this region in Brazil (VAlle et al., 2004), we intend to identify important genotypes to be used in parental crosses.

\section{MATERIAL AND METHODS}

\section{Sample collection}

The genotypes used in this study, from the Agronomic Institute (IAC) germplasm collection, in Campinas, São Paulo, Brazil, were divided into two groups: nine varieties for household consumption and eleven varieties used for several industrial purposes. Their origins and main agronomic characteristics are described in table 1. These cultivars are grown in the South Central region of Brazil, in the States of Santa Catarina, São Paulo, Paraná and Mato Grosso do Sul, and represent the most used cultivars for commercial purposes. Actually, IAC-12, IAC-13, IAC-14 and IAC-15 are strongly required by the industrial market. On the other hand, IAC 576-70 and Clone IAC 06-01 are commonly used for home consumption market. The other genotypes are maintained in the germplasm bank for breeding purposes.

\section{DNA extraction}

We followed the methodology described by Doyle and Doyle (1990), with modifications (Siqueira et al., 2009) for DNA extraction. Young expanded leaves were collected from each variety, dehydrated at $60^{\circ} \mathrm{C}$ for 72 hours and then ground. The extraction buffer composition was $0.1 \mathrm{M}$ Tris- $\mathrm{HCl}, \mathrm{pH} 8.0 ; 1.2 \mathrm{M} \mathrm{NaCl} ; 3 \%$ CTAB; $30 \mathrm{mM}$ EDTA, pH 8.0; 1\% Mercaptoethanol. Quantification was carried out in $4 \%$ polyacrylamide gel using silver nitrate as the staining method (BASSAM et al., 1991).

\section{PCR amplification}

The polymerase chain reactions were conducted in a final volume of $10.2 \mu \mathrm{L}$ containing $0.2 \mu \mathrm{L}$ Taq polymerase $\left(5 \mathrm{U} \mu \mathrm{L}^{-1}\right) ; 1.0 \mu \mathrm{L}$ Buffer (10X); $1.0 \mu \mathrm{L} \mathrm{MgCl}_{2}(50$ $\mathrm{mM}) ; 0.5 \mu \mathrm{L}$ Primer F $\left(5 \mathrm{pmol} \mu \mathrm{L}^{-1}\right) ; 0.5 \mu \mathrm{L}$ Primer $\mathrm{R}$ (5 pmol $\left.\mu \mathrm{L}^{-1}\right) ; 1.0 \mu \mathrm{L}$ dNTPs $(2.5 \mathrm{mM}$ of each); $3 \mu \mathrm{L}$ Milli-Q $\mathrm{H}_{2} \mathrm{O}$ and $3 \mu \mathrm{L}$ DNA $\left(5 \mathrm{ng} \mu \mathrm{L}^{-1}\right)$. Nine primers established by Chavarriaga-Aguirre et al. (1998) (GA-5, GA-12, GA-21, GA-126, GA-127, GA-131, GA134, GA-136 and GA-140) were used. PCR reactions 
Table 1. List of the 20 genotypes of cassava (Manihot esculenta) analyzed

\begin{tabular}{|c|c|c|c|c|c|}
\hline Cultivar & Abbreviation & Crossings & Use & Origin & Main traits ${ }^{(1)}$ \\
\hline IAC 12 & IAC 12 & Polycross of elite clones & Industrial & IAC (2) & $\begin{array}{l}\text { High dry matter content, adapted to a } \\
\text { prolonged hydric deficiency }\end{array}$ \\
\hline IAC 13 & IAC 13 & $\begin{array}{l}\text { Polycross of elite } \\
\text { varieties }\end{array}$ & Industrial & IAC & $\begin{array}{l}\text { High dry matter content, tolerant to low } \\
\text { fertile soils }\end{array}$ \\
\hline IAC 14 & IAC 14 & $\begin{array}{l}\text { Polycross of elite } \\
\text { varieties }\end{array}$ & Industrial & IAC & $\begin{array}{l}\text { High dry matter content, , tolerant to low } \\
\text { fertile soils, high bacteriosis resistance }\end{array}$ \\
\hline IAC 15 & IAC 15 & $\begin{array}{l}\text { SRT-59 Branca de Santa } \\
\text { Catarina x SRT1174- } \\
\text { Rainha }\end{array}$ & Industrial & IAC & $\begin{array}{c}\text { Low dry matter content, excellent quality } \\
\text { flour }\end{array}$ \\
\hline IAC Caapora & CAAP & $\begin{array}{c}\text { Open pollination of } \\
\text { SRT-59 Branca de Santa } \\
\text { Catarina }\end{array}$ & Industrial & IAC & $\begin{array}{l}\text { High dry matter content, vigorous, high } \\
\text { bacteriosis resistance }\end{array}$ \\
\hline IAC 90 & IAC 90 & $\begin{array}{l}\text { Open pollination of } \\
\text { SRT-1287 (Fiber) }\end{array}$ & Industrial & IAC & $\begin{array}{c}\text { High dry matter content, adapted to } \\
\text { high fertile soils, adapted to mechanized } \\
\text { planting }\end{array}$ \\
\hline $\begin{array}{l}\text { SRT - } 1445 \\
\text { (Fécula Branca) }\end{array}$ & FECBR & Landrace & Industrial & Paraná (3) & $\begin{array}{l}\text { High dry matter content, adapted to } \\
\text { mechanized planting }\end{array}$ \\
\hline $\begin{array}{l}\text { SRT - } 1335 \\
\text { (Espeto) }\end{array}$ & ESP & Landrace & Industrial & Paraná & $\begin{array}{l}\text { Medium dry matter content, adapted to } \\
\text { mechanized planting }\end{array}$ \\
\hline $\begin{array}{l}\text { SRT - } 1289 \\
\text { (Olho Junto) }\end{array}$ & OLHO & Landrace & Industrial & Paraná & $\begin{array}{l}\text { Extremely high dry matter content, low } \\
\text { height, susceptible to bacteriosis }\end{array}$ \\
\hline $\begin{array}{l}\text { SRT - } 1099 \\
\text { (Taquari) }\end{array}$ & TAQ & Unknown cross & Industrial & E.E. Taquari (3) & $\begin{array}{l}\text { High resistance to bacteriosis, vigorous, } \\
\text { high fertility in crossings, tolerant to mild } \\
\text { temperatures. }\end{array}$ \\
\hline $\begin{array}{l}\text { SRT - } 59 \\
\text { (Branca de } \\
\text { Santa Catarina) }\end{array}$ & BSC & Landrace & Industrial & $\begin{array}{l}\text { Santa } \\
\text { Catarina }\end{array}$ & $\begin{array}{l}\text { Low dry matter content, low adaptation to } \\
\text { mechanized planting, less cultivated lately, } \\
\text { high fertility in crossings }\end{array}$ \\
\hline IAC 576-70 & $576-70$ & $\begin{array}{l}\text { SRT-797 Ouro do Vale } x \\
\text { IAC } 14-18\end{array}$ & $\begin{array}{l}\text { Household } \\
\text { consumption }\end{array}$ & IAC & $\begin{array}{c}\text { Yellow flesh color, uniform roots and } \\
\text { good culinary qualities. Main variety } \\
\text { commercialized in the horticulture } \\
\text { markets }\end{array}$ \\
\hline $\begin{array}{l}\text { SRT } 1333 \\
\text { (Amarela) }\end{array}$ & SRT 1333 & Landrace & $\begin{array}{l}\text { Household } \\
\text { consumption }\end{array}$ & Coxim (MS) & $\begin{array}{l}\text { Yellow flesh color, uniform roots, excellent } \\
\text { agronomic traits, used in small markets }\end{array}$ \\
\hline $\begin{array}{l}\text { SRT } 1221 \\
\text { (Amarela) }\end{array}$ & SRT 1221 & Landrace & $\begin{array}{l}\text { Household } \\
\text { consumption }\end{array}$ & $\begin{array}{l}\text { São Pedro do } \\
\text { Turvo (SP) }\end{array}$ & $\begin{array}{l}\text { Yellow flesh color, uniform roots, used in } \\
\text { small regional markets }\end{array}$ \\
\hline $\begin{array}{l}\text { SRT - } 797 \\
\text { (Ouro do Vale/ } \\
\text { OURO) }\end{array}$ & OURO & Landrace & $\begin{array}{l}\text { Household } \\
\text { consumption }\end{array}$ & $\begin{array}{c}\text { Pindamo- } \\
\text { nhangaba (SP) }\end{array}$ & $\begin{array}{l}\text { Yellow flesh color, non-uniform roots, } \\
\text { excellent culinary quality, important in } \\
\text { urban agriculture }\end{array}$ \\
\hline Clone IAC 06-01 & $06-01$ & SRT $1221 \times$ IAC 576-70 & $\begin{array}{l}\text { Household } \\
\text { consumption }\end{array}$ & IAC & $\begin{array}{l}\text { Very yellow flesh color, source of genes } \\
\text { for high } \beta \text {-carotene content }\end{array}$ \\
\hline IAC 14-18 & 1418 & $\begin{array}{l}\text { Open pollination of } \\
\text { SRT-454 Gaxupé }\end{array}$ & $\begin{array}{l}\text { Household } \\
\text { consumption }\end{array}$ & IAC & $\begin{array}{c}\text { White flesh color, high dry matter content, } \\
\text { favorable architecture for cultural } \\
\text { practices }\end{array}$ \\
\hline IAC Jaçanã & JAÇ & $\begin{array}{l}\text { SRT } 524 \text { Aipim } \\
\text { Paraguaio } \\
\text { x IAC 5-165 }\end{array}$ & $\begin{array}{l}\text { Household } \\
\text { consumption }\end{array}$ & IAC & $\begin{array}{l}\text { White flesh color, vigorous, excellent } \\
\text { culinary quality }\end{array}$ \\
\hline $\begin{array}{l}\text { SRT - } 1540 \\
\text { (Três Meses) }\end{array}$ & TRÊS & Landrace & $\begin{array}{l}\text { Household } \\
\text { consumption }\end{array}$ & Paraná & $\begin{array}{l}\text { White flesh color, source of genes for low } \\
\text { height and precocity }\end{array}$ \\
\hline $\begin{array}{l}\text { IAC 24-2 } \\
\text { (Mantiqueira) }\end{array}$ & MANT & $\begin{array}{l}\text { Open pollination of SRT- } \\
120 \text { Santa }\end{array}$ & $\begin{array}{l}\text { Household } \\
\text { consumption }\end{array}$ & IAC & $\begin{array}{l}\text { White flesh color, high spatial stability, } \\
\text { identified in various world regions as CMC } \\
40\end{array}$ \\
\hline
\end{tabular}

(1) Important traits for a cultivar and/or a parent in plant breeding programs. $\left({ }^{2}\right)$ Developed by the plant breeding program of the Agronomic Institute (IAC), Campinas, São Paulo, Brazil. $\left(^{3}\right)$ Developed by the plant breeding program of the Experimental Station of Taquari, Taquari, Rio Grande do Sul, Brazil. SRT - landraces belonging to the IAC cassava germplasm bank. Varieties - genotypes cultivated by agriculturists; Clones - elite genotypes from the IAC plant breeding program.

were performed at a BioRad MyCycler Thermal Cycler, under the following conditions: $4 \mathrm{~min}$ at $95^{\circ} \mathrm{C}, 29$ cycles of $1 \mathrm{~min}$ at $95^{\circ} \mathrm{C}, 2 \mathrm{~min}$ at the annealing temperature defined for each primer and $2 \mathrm{~min}$ at $72{ }^{\circ} \mathrm{C}$, and the final extension stage of $1 \mathrm{~min}$ at $72{ }^{\circ} \mathrm{C}$. The annealing temperatures used were $52^{\circ} \mathrm{C}$ for GA-134, $54{ }^{\circ} \mathrm{C}$ for GA-131, $57^{\circ} \mathrm{C}$ for GA-12 and GA-126, $59^{\circ} \mathrm{C}$ for GA-
127, $60^{\circ} \mathrm{C}$ for GA-5, $62^{\circ} \mathrm{C}$ for GA-21 and GA-140, and $64^{\circ} \mathrm{C}$ for GA-136. Amplified fragments were separated in $6 \%$ non-denaturing polyacrylamide gels at an initial voltage of $60 \mathrm{~V}$ for $30 \mathrm{~min}$ and a final voltage of $120 \mathrm{~V}$ for $3 \mathrm{~h}$ and $30 \mathrm{~min}$, using a 10\% TBE $10 \mathrm{X}$ buffer. Microsatellites bands were identified by silver nitrate methodology (BAssam et al., 1991). 


\section{Statistical analysis}

Allele frequencies and the parameters average number of alleles per polymorphic locus, percentage of polymorphic loci, observed heterozygosity $\left(\bar{H}_{0}\right)$, gene diversity $(\bar{H})$, and the inbreeding coefficient of Wright were estimated considering the two groups (industrial and household consumption varieties), with the GDA (Genetic Data Analysis) software (LewIS and ZAYKIN, 2001). The modified Rogers' distance between accessions was also estimated using the TFPGA software (Miller, 1997). A cluster analysis was then obtained with the modified Rogers' distance matrix and the UPGMA method, using DARwin 5.0 software (Perrier et al., 2003).

\section{RESULTS AND DISCUSSION}

Using nine SSR loci, we found high polymorphism $(100 \%)$ for all loci in both types of cassava genotypes. Also, we identified high genetic variability among the 20 genotypes analyzed as well as within the two groups (varieties for industrial use and household consumption), indicating no genetic vulnerability in the cassava grown in the South Central region of Brazil. The number of alleles ranged from two (loci GA-5 and GA-134) to seven (GA-127) alleles per loci. The average observed heterozygosity per loci $\left(H_{\mathrm{o}}\right)$ was 0.34 , lower than the gene diversity value per loci $\left(H_{\mathrm{e}}=0.58\right)$. When the observed heterozygosity is lower than expected, which is our case, this discrepancy may be attributed to causes such as inbreeding and a heterozygous deficit. Our results could be attributed to the many crosses and inbreeding processes performed at the Agronomic Institute breeding program, which occurred toward different directions, in a way to select particular traits aiming at different purposes. The results observed here are expected because the evaluated genotypes were selected to form two different groups, each one with similar traits, i.e., the industrial genotypes were conducted to produce higher flour content and the home consumption varieties to produce good culinary characteristics.

The number of alleles per polymorphic locus was higher in varieties for household consumption (4.0) compared with the industrial varieties (2.8), while the average regarding this parameter in both groups was 3.4 (Table 2). Observed heterozygosity $\left(\bar{H}_{0}=0.433\right)$ and gene diversity $\left(\bar{H}_{e}=0.642\right)$ values were higher for the household consumption varieties when compared with the industrial varieties $\left(\bar{H}_{o}=0.309\right.$ and $\left.\bar{H}_{e}=0.467\right)$. The average values for observed heterozygosity and gene diversity were $\bar{H}_{0}=$ 0.371 and $\bar{H}_{e}=0.555$, respectively. The fixation index of Wright was established in such a way that the two groups (household consumption and industrial cassava) presented an excess of homozygotes (0.370) on average.
Table 2. Genetic parameters estimated for industrial and household cassava varieties. Number of individuals analyzed $(N)$, average number of alleles per polymorphic locus $(\bar{A})$, percentage of polymorphic loci $(P)$, average observed heterozygosity $\left(\bar{H}_{0}\right)$, gene diversity $(\bar{H})$ and fixation index of Wright $(f)$ for cassava (Manihot esculenta) varieties for industrial and household consumption

\begin{tabular}{lcccccc} 
Varieties & $N$ & $\bar{A}$ & $P(\%)$ & $\bar{H}_{o}$ & $\bar{H}_{e}$ & $f$ \\
Industrial & 11 & 2.8 & 100 & 0.309 & 0.467 & 0.410 \\
$\begin{array}{l}\text { Household } \\
\text { consumption }\end{array}$ & 9 & 4.0 & 100 & 0.433 & 0.642 & 0.330 \\
Mean & & 3.4 & 100 & 0.371 & 0.555 & 0.370 \\
\hline
\end{tabular}

Siqueira et al. (2009) detected high levels of polymorphism (95.5\%) when assessing 42 cassava landraces from five regions in Brazil with SSR markers; AsANTE and OfFEI (2003) found $97.5 \%$ of polymorphism in 50 cassava accessions using four RAPD primers and CABRAL et al. (2002), with isoenzymatic markers, registered $100 \%$ of polymorphism, evaluating 200 accessions from several regions in Brazil. MкuмBiRA et al. (2003) also reported high levels of polymorphism using seven microsatellite loci to evaluate 277 genotypes cultivated in Malawi, Africa. The varieties for household consumption in this study showed a high number of alleles per locus (4.0). Fregene et al. (2003), analyzing 283 cassava accessions from various countries using 67 microsatellite loci, found similar values, with an average of 4.03 alleles per locus. When analyzing 36 African landrace cultivars and 27 elite lines selected from 400 elite cassava lines maintained at IITA (International Institute of Tropical Africa), Ibadan, with 50 SSR markers, RaJi et al. (2009) found 3.6 and 3.5 alleles per locus, respectively, for the landraces and elite cultivars.

In the literature, data have focused on regional and even worldwide cassava collections, while our study refers to potential genotypes from breeding programs of cassava which were also submitted to a careful selection process, preserving the high diversity existing in the original material. Among the genotypes used in our study, four varieties for industrial use (FECBR, ESP, OLHO and BSC) and four varieties for household consumption (SRT1333, SRT1221, OURO and TRÊS) were selected directly from landraces, while the other varieties were obtained from specific crosses (IAC15, 576-70, 06-01, JAÇ and TAQ), from polycrosses of elite clones (IAC12, IAC13 and IAC14), or from open pollination (CAAP, IAC90, 14-18 and MANT), the majority originated from the plant breeding program leaded by IAC. The main feature observed in the varieties for industrial use is the high dry matter (DM) content (IAC12, IAC13, IAC14, CAAP, IAC90, FECBR and OLHO). Adaptability to mechanized planting (IAC90, FECBR and ESP) is also an appreciated trait in extensive crops, while other characteristics such as tolerance to low-fertile soils (IAC13 and IAC14) and resistance to bacteriosis (Xanthomonas campestris pv. 
manihotis) (IAC14, CAAP and TAQ) are also desirable for the varieties for industrial use (Table 1). On the other hand, flesh-colored cassava (a regional preference) and the excellent culinary quality are among the main properties expected in varieties for household consumption.

The higher genetic diversity observed in varieties for household consumption in this study, as discussed above, is possibly due to larger and more subjective selection pressures when compared to the varieties for industrial use. Important traits for the industrial varieties are productivity, resistance to bacteriosis, DM yield and adaptability to mechanized planting (VILLELA et al., 1985), while other characteristics received less attention. On the other hand, taking into account the regional aspects and different selection processes, varieties for household consumption have a number of traits with similar importance: productivity, resistance to bacteriosis, and an extensive group of sensorial features (color, flavor, baking quality, cooked mass type and texture) which form the main features of cassava. Therefore, varieties for household consumption probably contain a higher genetic diversity to comply with demand for sensorial traits.

The dendrogram obtained in the cluster analysis indicated a separation of the two types of varieties (household and industrial varieties), with a few exceptions (Figure 1), although the bootstrap analysis did not confirm the consistency of these groups. These results can be explained by a low number of loci evaluated here. The use of a higher number of SSR loci, available at MвA et al. (2001) and RAJI et al. (2009), might contribute for the increase in the consistency of these groups. But still, we can conclude that a tendency for separation of the two types of varieties exists. Two groups contained most of the industrial varieties, including three household varieties (MANT, TRÊS

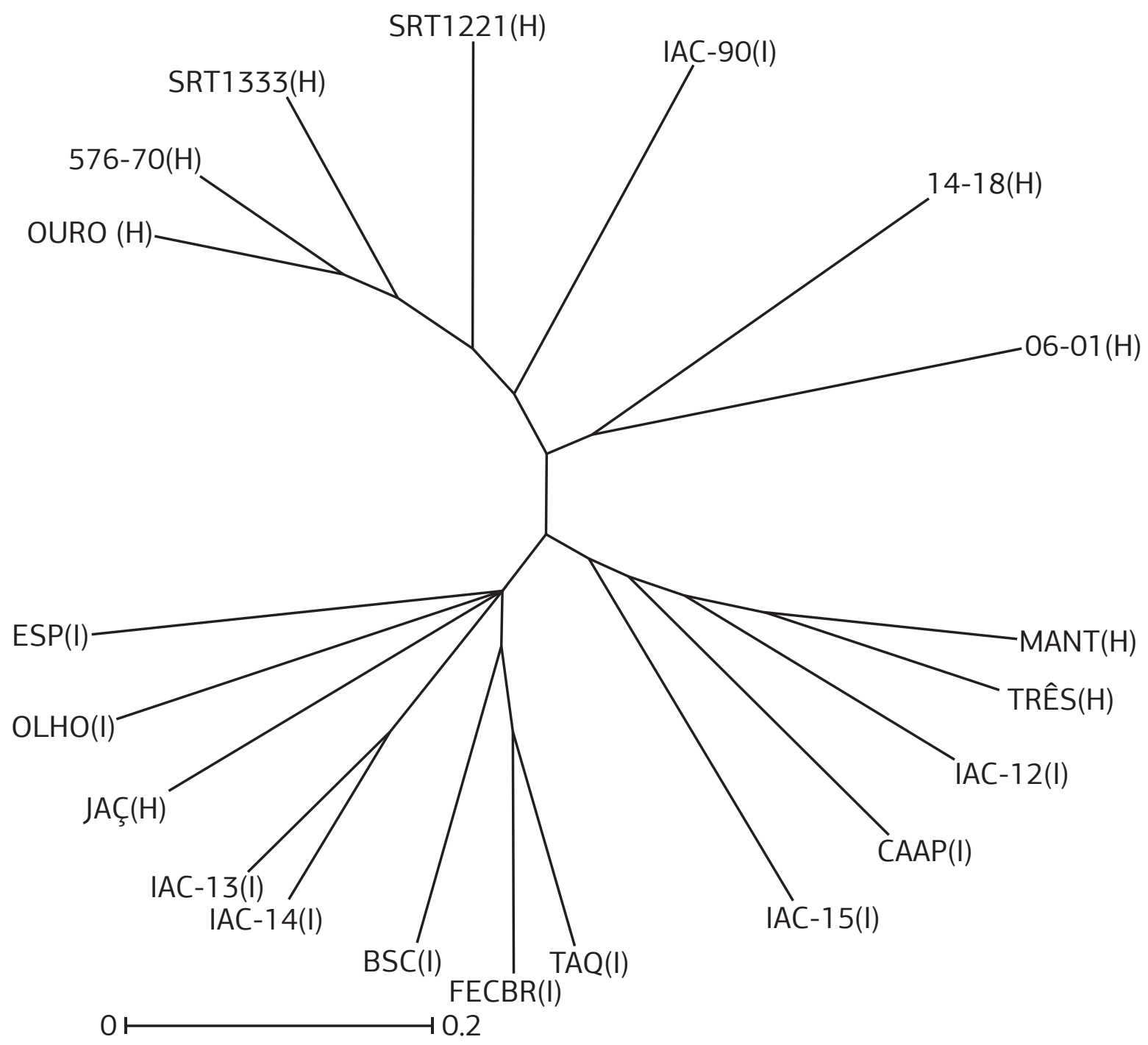

Figure 1. Dendrogram based on UPGMA method and modified Rogers' genetic distance for nine microsatellite loci and 20 cassava genotypes, among which 11 varieties for industrial use (I) and nine for household consumption $(\mathrm{H})$. 
Table 3. Modified Rogers' genetic distance among 20 cassava (Manihot esculenta) genotypes

\begin{tabular}{|c|c|c|c|c|c|c|c|c|c|c|c|c|c|c|c|c|c|c|c|}
\hline & IAC12 & IAC13 & IAC14 & IAC15 & CAAP & IAC9O & $\begin{array}{c}\text { FEC } \\
\text { BR }\end{array}$ & ESP & OLHO & TAQ & BSC & $\begin{array}{l}576- \\
70\end{array}$ & $\begin{array}{l}\text { SRT } \\
1333\end{array}$ & $\begin{array}{l}\text { SRT } \\
1221\end{array}$ & OURO & 601 & 1418 JAÇ & TRÊS & MANT \\
\hline IAC12 & 0.000 & & & & & & & & & & & & & & & & & & \\
\hline $\mathrm{IAC13}$ & 0.577 & 0.000 & & & & & & & & & & & & & & & & & \\
\hline IAC14 & 0.553 & 0.289 & 0.000 & & & & & & & & & & & & & & & & \\
\hline IAC15 & 0.500 & 0.667 & 0.645 & 0.000 & & & & & & & & & & & & & & & \\
\hline CAAP & 0.471 & 0.577 & 0.500 & 0.645 & 0.000 & & & & & & & & & & & & & & \\
\hline IAC90 & 0.782 & 0.687 & 0.745 & 0.667 & 0.850 & 0.000 & & & & & & & & & & & & & \\
\hline FECBR & 0.745 & 0.553 & 0.527 & 0.667 & 0.624 & 0.601 & 0.000 & & & & & & & & & & & & \\
\hline ESP & 0.553 & 0.500 & 0.471 & 0.553 & 0.645 & 0.601 & 0.500 & 0.000 & & & & & & & & & & & \\
\hline OLHO & 0.687 & 0.471 & 0.500 & 0.624 & 0.645 & 0.687 & 0.527 & 0.577 & 0.000 & & & & & & & & & & \\
\hline TAQ & 0.745 & 0.527 & 0.500 & 0.645 & 0.687 & 0.577 & 0.333 & 0.527 & 0.471 & 0.000 & & & & & & & & & \\
\hline BSC & 0.782 & 0.667 & 0.601 & 0.687 & 0.687 & 0.624 & 0.471 & 0.667 & 0.527 & 0.441 & 0.000 & & & & & & & & \\
\hline $576-70$ & 0.661 & 0.729 & 0.707 & 0.707 & 0.771 & 0.559 & 0.707 & 0.612 & 0.685 & 0.637 & 0.530 & 0.000 & & & & & & & \\
\hline SRT1333 & 0.771 & 0.771 & 0.791 & 0.791 & 0.866 & 0.530 & 0.729 & 0.685 & 0.771 & 0.637 & 0.612 & 0.306 & 0.000 & & & & & & \\
\hline SRT1221 & 0.687 & 0.667 & 0.687 & 0.687 & 0.764 & 0.500 & 0.601 & 0.577 & 0.667 & 0.527 & 0.667 & 0.468 & 0.354 & 0.000 & & & & & \\
\hline OURO & 0.707 & 0.726 & 0.745 & 0.707 & 0.816 & 0.577 & 0.707 & 0.645 & 0.667 & 0.707 & 0.577 & 0.250 & 0.354 & 0.553 & 0.000 & & & & \\
\hline 601 & 0.833 & 0.764 & 0.782 & 0.913 & 0.726 & 0.764 & 0.764 & 0.850 & 0.667 & 0.745 & 0.577 & 0.612 & 0.685 & 0.745 & 0.645 & 0.000 & & & \\
\hline 1418 & 0.667 & 0.764 & 0.745 & 0.687 & 0.726 & 0.707 & 0.745 & 0.667 & 0.707 & 0.799 & 0.624 & 0.500 & 0.612 & 0.687 & 0.441 & 0.577 & 0.000 & & \\
\hline JAÇ & 0.667 & 0.577 & 0.553 & 0.687 & 0.553 & 0.726 & 0.500 & 0.577 & 0.500 & 0.553 & 0.577 & 0.661 & 0.791 & 0.667 & 0.667 & 0.667 & $\begin{array}{ll}0.687 & 0.000\end{array}$ & & \\
\hline TRÊS & 0.441 & 0.624 & 0.553 & 0.601 & 0.527 & 0.764 & 0.726 & 0.553 & 0.667 & 0.745 & 0.745 & 0.637 & 0.771 & 0.667 & 0.645 & 0.799 & $0.601 \quad 0.527$ & 0.000 & \\
\hline MANT & 0.441 & 0.577 & 0.601 & 0.553 & 0.553 & 0.707 & 0.667 & 0.527 & 0.645 & 0.726 & 0.745 & 0.637 & 0.707 & 0.601 & 0.601 & 0.816 & $\begin{array}{lll}0.553 & 0.577\end{array}$ & 0.333 & 0.000 \\
\hline
\end{tabular}

and JAÇ), all three with white flesh color. The other group contained the household varieties, most of them with yellow flesh color, except for 14-18, and one industrial variety (IAC-90). Yellow flesh color is a very desirable trait in terms of higher nutritional quality. Some of these genotypes also present desirable culinary qualities, OURO and 576-70, the latter being the most commercialized variety in horticulture markets for its excellent agronomic and culinary features (VIllele et al., 1985), and also uniform roots (576-70, SRT1333 and SRT1221).

Varieties SRT1333 and SRT1221, which have a small genetic distance $(0,354)$ between each other (Table 3$)$, derived from different locations [São Pedro do Turvo, SP (SRT1221) and Coxim, MS (SRT1331)]. These two varieties, widely distributed in the States of Santa Catarina, São Paulo, Mato Grosso do Sul and Paraná, also show high morphological similarity, which added to the similarity detected here, indicates that they probably have a common origin.

Genetic divergence of genotypes two by two (Table 3 ) is an important parameter to be considered when selecting species for breeding purposes, once divergent genotypes should be selected for a plant breeding program. For instance, CLONE 06-01 showed high genetic distances, above 0.80 , when considering the varieties IAC12 (0.833), IAC15 (0.913) and ESP (0.850) (Table 3). CLONE 0601 is a variety of household consumption, whereas the three cultivars that could be chosen as possible parents are industrial varieties. The household consumption variety 14-18 also showed higher genetic divergence with the industrial varieties IAC 13 (0.764) and TAQ (0.799). The industrial variety IAC90 also presented high genetic distances when compared to the industrial varieties IAC12 (0.782) and CAAP (0.850).
Crossings between the two groups (house consumption and industrial use varieties) are not usually carried out because there is a risk of introducing undesirable genes from one to the other group, which justifies the tendency for the separation of the two groups. This problem is worse when genes from varieties for industrial use are transferred to varieties for household consumption, once these genes are hardly eliminated, especially genes that affect the sensorial qualities. Interestingly, this concern is not reciprocal because the organoleptic properties are not considered for industrial use. Therefore, using varieties for household consumption as a parent in breeding programs to develop industrial varieties may be satisfactory. Consequently, it seems promising to the both varieties 14-18 and 06-01 as parents in order to obtain varieties for industrial use, considering their high genetic dissimilarity with several varieties for this use, which is a premise for heterosis and for transferring some of their interesting traits, such as yellow (06-01) and white (14-18) roots, high dry matter content and favorable architecture for cultural practices (14-18), among others. Furthermore, the other divergent variety, IAC90, has a potential as parental variety, due to interesting agronomic traits, such as high DM content, adaptability to mechanized planting and to high fertile soils.

\section{CONCLUSION}

The cassava genotypes assessed in this study, represented in the living germplasm collection of the Agronomic Institute (IAC), present high levels of polymorphism. Varieties for household consumption attain higher genetic variability, probably due to high priority placed on 
selection of different sensorial traits. The genetic variability found in both groups of varieties, for industrial use and for household consumption, is enough to allow the choice for contrasting parental genotypes to be used in crossings to obtain new recombinant genotypes.

\section{ACKNOWLEDGEMENTS}

Financial support for this research work was provided by State of São Paulo Research Foundation (FAPESP - 2005/53407-4). The authors also wish to thank the National Council for Scientific and Technological Development (CNPq) for the scholarships granted and the journal reviewers for their excellent suggestions.

\section{REFERENCES}

AMOROZO, M.C.M. Management and conservation of Manihot esculenta Crantz. germplasm by traditional farmers in Santo Antônio do Leverger, Mato Grosso State, Brazil. Etnoecológica, v.4, p.69-83, 2000.

AMOROZO, M.C.M. Maintenance and management of agrobiodiversity in small-scale agriculture. Functional Ecosystems and Communities, v.2, p.11-20, 2008.

ASANTE, I.K.; OFFEI, S.K. RAPD-based genetic diversity study of fifty cassava (Manihot esculenta Crantz) genotypes. Euphytica, v.131, p.113-119, 2003.

BASSAM, B.J.; CAETANO-ANOLLES, G.; GRESSHOFF, P.M. Fast and sensitive silver staining of DNA in polyacrylamide gels. Analytical Biochemistry, v.196, p.80-83, 1991.

BEECHING, J.R.; MARMEY, P.; GAVALDA, M.C.; NOIROT, M.; HAYSON, H.R.; HUGHES, M.A.; CHARRIER, A. An assessment of genetic diversity within a collection of cassava (Manihot esculenta Crantz) germplasm using molecular markers. Annals of Botany, v.72, p.515-520, 1993.

CABRAL, B.L.R.; SOUZA, J.A.B.; ANDO, A.; VEASEY, E.A.; CARDOSO, E.R. Isoenzymatic variability of cassava accessions from different regions in Brazil. Scientia Agricola, v.59, p.521-527, 2002.

CARVALHO, L.J.C.B.; SCHAAL, B.A. Assessing genetic diversity in the cassava (Manihot esculenta Crantz) germplasm collection in Brazil using PCR-based markers. Euphytica, v.120, p.133-142, 2001.

CHAVARRIAGA-AGUIRRE, P.; MAYA, M.M.; BONIERBALE, M.W.; KRESOVICH, S.; FREGENE, M.A.; TOHME, J.; KOCHERT, G. Microsatellites in cassava (Manihot esculenta Crantz): discovery, inheritance and variability. Theoretical and Applied Genetics, v.97, p.493-501, 1998.

DOYLE, J.J.; DOYLE, J.L. Isolation of plant DNA from fresh tissue. Focus, v.12, p.13-15, 1990.

FAO. Food and Agriculture Organization of the United Nations. Available at: <http://www.fao.org>. Accessed in: 2 Jun 2011.
FERREIRA, C.F.; ALVES, E.; PESTANA, K.N.; JUNGHANS, D.T.; KOBAYASHI, A.K.; SANTOS, V.J.; SILVA, R.P.; SILVA, P.H.; SOARES, E.; FUKUDA, W. Molecular characterization of cassava (Manihot esculenta Crantz) with yellow-orange roots for beta-carotene improvement. Crop Breeding and Applied Biotechnology, v.8, p.23-29, 2008.

FREGENE, M.A.; SUAREZ, M.; MKUMBIRA, J.; KULEMBEKA, H.; NDEDYA, E.; KULAYA, A.; MITCHEL, S.; GULLBERG, U.; ROSLING, H.; AGO, D.; KRESOVICH, $S$. Simple sequence repeat marker diversity in cassava landraces: genetic diversity and differentiation in an asexually propagated crop. Theoretical and Applied Genetics, v.107, p.1083-1093, 2003.

IBGE. Brazilian Institute of Geography and Statistics. Available at: <http://www.ibge.com.br>. Accessed in: 24 Feb. 2007.

KAWUKI, R.S.; FERGUSON, M.; LABUSCHAGNE, M.T.; HERSELMAN, L.; ORONE, J.; RALIMANANA, I.; BIDIAKA, M.; LUKOMBO, S.; KANYANGE, M.C.; GASHAKA, G.; MKAMILO, G.; GETHI, J.; OBIERO, H. Variation in qualitative and quantitative traits of cassava germplasm from selected national breeding programmes in sub-Saharan Africa. Field Crops Research, v.122, p.151-156, 2011.

LEWIS, P.O.; ZAYKIN, D. Genetic data analysis: computer program for the analysis of allelic data. Version 1.0 (d12), 2001. Available at: http://lewis.eeb.uconn.edu/. Accessed in: 20 Oct. 2007.

MBA, R.E.C.; STEPHENSON, P.; MELZER, S.; NKUMBIRA, J.; GUllBERG, U.; APEL, K.; GALE, M.; TOHME, J.; FREGENE, M. Simple sequence repeat (SSR) markers survey of the cassava (Manihot esculenta Crantz) genome: towards an SSRbased molecular genetic map of cassava. Theoretical and Applied Genetics, v.102, p.21-31, 2001.

MILLER, M. Tools for population genetic analyses (TFPGA) 1.3: A windows program for analysis of allozyme and molecular population genetic data. Available at: http: //www.public.asu.edu/. Accessed in: 20 May 2007.

MKUMBIRA, J.; CHIWONA-KARLTUN, L.; LAGERCRANTZ, U.; MAHUNGU, N.M.; SAKA, J.; MHONE, A.; BOKANGA, M.; BRIMER, L.; GULLBERG, U.; ROSLING, H. Classification of cassava into 'bitter' and 'cool' in Malawi: From farmers' perception to characterization by molecular markers. Euphytica, v.132, p.7-22, 2003.

MÜHLEN, G.S.; MARTINS, P.S.; ANDO, A. Genetic diversity of cassava folk varieties, assessed by DNA markers. Scientia Agricola, v. 57, p. 319-328, 2000.

PERONI, N.; KAGEYAMA, P.Y.; BEGOSSI, A. Molecular differentiation, diversity, and folk classification of "sweet" and "bitter" cassava (Manihot esculenta) in Caiçara and Caboclo management systems (Brazil). Genetic Resources and Crop Evolution, v.54, p.1333-1349, 2007.

PERRIER, X.; FLORI, A.; BONNOT, F. Data analysis methods. In: HAMON, P.; SEGUIN, M.; PERRIER, X.; GLASZMANN, J. C. (Ed.). Genetic diversity of cultivated tropical plants. Enfield: Science Publishers, 2003. p.43-76. 
RAJI, A.A.J.; FAWOLE, I.; GEDIL, M.; DIXON, A.G.O. Genetic differentiation analysis of African cassava (Manihot esculenta) landraces and elite germplasm using amplified fragment length polymorphism and simple sequence repeat markers. Annals of Applied Biology, v.155, p.187-199, 2009.

ROA, A.C.; CHAVARRIAGA-AGUIRRE, P.; DUQUE, M.C.; MAYA, M.M.; BONIERBALE, M.W.; IGLESIAS, C.; TOHME, J. Cross-species amplification of cassava (Manihot esculenta) (Euphorbiaceae) microsatellites: allelic polymorphism and degree of relationship. American Journal of Botany, v.87, p.1647-1655, 2000.

SIQUEIRA, M.V.B.M.; PINHEIRO, T.T.; BORGES A; VALLE, T.L.; ZATARIM, M.; VEASEY, E.A. Microsatellites polymorphism in cassava landraces from the Cerrado biome, Mato Grosso do Sul, Brazil. Biochemical Genetics, v. 48, p. 879-895, 2010.

SIQUEIRA, M.V.B.M.; SILVA, J.R.Q.; BRESSAN, E.A.; BORGES, A.; PEREIRA, K.J.C.; PINTO, J.G.; VEASEY, E.A.
Genetic characterization of cassava (Manihot esculenta) landraces in Brazil assessed with simple sequence repeats. Genetics and Molecular Biology, v.32, p.104-110, 2009.

VALLE, T.L.; CARVALHO, C.R.L.; RAMOS, M.T.B.; MÜHLEN, G.S.; VILLELA, O.V. Conteúdo cianogênico em progênies de mandioca originadas do cruzamento de variedades mansas e bravas. Bragantia, v.63, p.221-226, 2004.

VILLELA, O.V.; PEREIRA, A.S.; LORENZI, J.O.; VALLE, T.L.; MONTEIRO, D.A.; RAMOS, M.T.; SCHMITD, N.C. Competição de clones de mandioca (Manihot esculenta Crantz) selecionados para mesa e indústria. Bragantia, v.44, p.667-678, 1985.

ZACARIAS, A.M.; BOTHA, A.M.; LABUSCHAGNE, M.T.; BENESI, I.R.M. Characterization and genetic distance analysis of cassava (Manihot esculenta Crantz) germplasm from Mozambique using RAPD fingerprinting. Euphytica, v.138, p.49-53, 2004. 